ECONOMIC GROWTH CENTER

YALE UNIVERSITY

P.O. Box 208269

New Haven, CT 06520-8269

http://www.econ.yale.edu/ egcenter/

CENTER DISCUSSION PAPER NO. 871

\title{
FAMILIES, HUMAN CAPITAL, AND SMALL BUSINESS: EVIDENCE FROM THE CHARACTERISTICS OF BUSINESS OWNERS SURVEY
}

\author{
Robert W. Fairlie \\ Yale University \& \\ University of California, Santa Cruz \\ and \\ Alicia Robb \\ Board of Governors of the Federal Reserve System \& \\ Foundation for Sustainable Development
}

October 2003

Notes: Center Discussion Papers are preliminary materials circulated to stimulate discussions and critical comments.

This research was partially funded by the Russell Sage Foundation. Research for this paper was conducted at the Center for Economic Studies at the U.S. Census Bureau. The views expressed here are solely the responsibility of the authors and should not be interpreted as reflecting the views of the Russell Sage Foundation, the U.S. Census Bureau, or the Board of Governors of the Federal Reserve System. We would like to thank Ken Brevoort, Tom Dunn, and seminar participants at the Winter 2003 Meetings of the American Economic Association for their comments. Bill Koch and Garima Vasishtha provided excellent research assistance.

This paper can be downloaded without charge from the Social Science Research Network electronic library at: $\underline{\text { http://ssrn.com/abstract }=464243}$

An index to papers in the Economic Growth Center Discussion Paper Series is located at:

http://www.econ.yale.edu/ egcenter/research.htm 


\title{
Families, Human Capital, and Small Business: Evidence from the Characteristics of Business Owners Survey
}

Robert W. Fairlie

rfairlie@ucsc.edu

Alicia Robb

alicia@fsdinternational.org

\begin{abstract}
Using data from the confidential and restricted-access Characteristics of Business Owners (CBO) Survey, we provide some suggestive evidence on the causes of intergenerational links in business ownership and the related issue of how having a family business background affects small business outcomes. Estimates from the CBO indicate that more than half of all business owners had a self-employed family member prior to starting their business. Conditional on having a self-employed family member, less than 50 percent of small business owners worked in that family member's business. In contrast, estimates from regression models conditioning on business ownership indicate that having a self-employed family member plays only a minor role in determining small business outcomes, whereas the business human capital acquired from prior work experience in a family member's business appears to be very important for business success. Estimates from the $\mathrm{CBO}$ also indicate that only 1.6 percent of all small businesses are inherited suggesting that the role of business inheritances in determining intergenerational links in self-employment is limited at best.
\end{abstract}

Keywords: Business Outcomes, Self-Employment, Entrepreneurship, Families, Human Capital. JEL Classification: M13, J24. 


\section{Introduction}

The literature on self-employment and small business ownership has grown rapidly in the past several years. The upsurge in interest is at least partly due to arguments that small businesses create a disproportionate share of new jobs in the economy, represent an important source of innovation, and have a notable effect on political decisions in the United States (see Birch 1979, Brown, Hamilton and Medoff 1990, and Acs 1999 for example). In addition, many academicians and policymakers view self-employment as a route out of poverty and as an alternative to unemployment or discrimination in the labor market. ${ }^{1}$ Several states and the federal government are currently promoting self-employment as a way to leave the welfare and unemployment insurance rolls, and there exist a plethora of governmental and private programs promoting business ownership among minorities, women, and other disadvantaged groups. $^{2}$ Finally, recent research suggests that the self-employed earn more on average than wage and salary workers (see Borjas 1999 for example).

An important finding in the rapidly growing literature on self-employment is that the probability of self-employment is substantially higher among the children of business owners than among the children of non-business owners (see Lentz and Laband 1990, Fairlie 1999, Dunn and Holtz-Eakin 2000, and Hout and Rosen 2000). These studies generally find that an individual who had a self-employed parent is roughly two to three times more likely to be self-employed than someone who did not have a self-employed

\footnotetext{
${ }^{1}$ See Glazer and Moynihan (1970), Light (1972, 1979), Sowell (1981), Moore (1983), and Bates (1997).

${ }^{2}$ See Guy, Doolittle, and Fink (1991) and Raheim (1997) for descriptions of the welfare program, U.S. Department of Labor (1992), Benus et al. (1995) and Vroman (1997) for descriptions of the UI program, and Balkin (1989), Bates (1993) and Severens and Kays (1999) for descriptions of programs for other disadvantaged groups.
} 
parent. Although the intergenerational transmission of business ownership is strong, the underlying causes of intergenerational links in business ownership have not been identified in the literature. They may be due to the acquisition of general business or managerial experience in family-owned businesses ("general business human capital"), the acquisition of industry- or firm-specific business experience in family-owned businesses ("specific business human capital"), inheritances of businesses, or a correlation among family members in preferences for entrepreneurial activities.

Using data from the Characteristics of Business Owners (CBO), we provide some suggestive evidence on the importance of these factors and explore the related question of whether having a self-employed parent or other family member improves small business outcomes. Although strong intergenerational links in self-employment have been repeatedly documented in the literature, the effects on small business outcomes conditioning on ownership are essentially unknown. We also estimate the independent effects of having a self-employed family member, prior work experience in that family member's business, and prior work experience in a similar business on small business outcomes. The results have implications for the roles that general and specific business human capital and the correlation across family members in entrepreneurial preferences play in determining business success. ${ }^{3}$ Another question that we examine is whether business inheritances are an important method of intergenerational transmission of business ownership. Previous research analyzing employer businesses from the National

\footnotetext{
${ }^{3}$ Using the National Longitudinal Surveys (NLS), Dunn and Holtz-Eakin (2000) find that the intergenerational correlation in self-employment is strongest for successfully self-employed parents suggesting that the transmission of business skills instead of similarities in tastes for the self-employed lifestyle drives the rela tionship between parents' and children's self-employment propensities. They also find that self-employed sons follow their father's occupation in only 32 percent of cases suggesting that the business expertise being passed within families is not only
} 
Federation of Independent Businesses (NFIB) finds that 14.2 percent of businessmen inherited their businesses (Lentz and Laband 1990), however, these businesses are much larger than the typical small business included in the CBO.

Previous studies have not explored these questions primarily because only a few nationally representative datasets contain information on parental and family selfemployment and business inheritances, and to our knowledge, the CBO is the only nationally representative dataset containing information on prior work experience in businesses owned by family members and prior work experience in businesses providing similar goods and services. ${ }^{4}$ The $\mathrm{CBO}$ contains detailed information on the characteristics of both the business and the owner, but has been used by only a handful of researchers. The lack of use appears to be primarily due to difficulties in accessing and reporting results from these confidential, restricted-access data. All research using the CBO must be conducted in a Census Research Data Center or at the Center for Economic Studies (CES) after approval by the CES and IRS, and all output must pass strict disclosure regulations.

\section{Data}

The 1992 Characteristics of Business Owners (CBO) survey was conducted by the U.S. Bureau of the Census to provide economic, demographic and sociological data on minority, women and non- minority male business owners and their business activities (see U.S. Department of Commerce 1997, Bates 1990a, Headd 1999, and Robb 2000 for more details on the CBO). The survey was sent to more than 75,000 firms and 115,000

specific to the types of business chosen by these sons.

${ }^{4}$ The CBO also contains information on prior work experience in a managerial capacity. 
owners who filed an IRS form 1040 Schedule C (individual proprietorship or selfemployed person), 1065 (partnership), or $1120 \mathrm{~S}$ (subchapter $\mathrm{S}$ corporation). ${ }^{5}$ Only firms with $\$ 500$ or more in sales were included. The businesses included in the CBO represent nearly 90 percent of all businesses in the United States (Department of Commerce, 1996b). Response rates for the firm and owners surveys were approximately 60 percent. All estimates reported below use sample weights that adjust for survey non-response (Headd, 1999).

The $\mathrm{CBO}$ is unique in that it contains information on both the characteristics of business owners and the characteristics of their businesses. Examples of owner characteristics include marital status, education, detailed work experience, family business background, hours and weeks worked in the business, and health insurance. Detailed information on how the owner acquired the business and on the sources of capital s/he used to start or acquire the business is also available. Business characteristics include closure, profits, sales, employment, industry, startup capital, age of business, legal form of organization, employee composition, customer base, physical location, and exports along with many others.

A major advantage of the $\mathrm{CBO}$ over other nationally representative datasets for this analysis is the availability of measures of business ownership among family members. In particular, the CBO contains information on business inheritances, business ownership among family members, and prior work experience in a family member's business. The main disadvantage is that the $\mathrm{CBO}$ does not contain information on a comparison group of wage/salary workers. Therefore, we cannot directly explore the

\footnotetext{
${ }^{5}$ Larger $\mathrm{C}$ corporations were not included because of the difficulty in asking owner questions for many investors. $\mathrm{C}$ corporations as a tax filing status, however, are becoming less popular relative
} 
determinants of business ownership. Instead, we examine the determinants of several business outcomes, such as closure rates, sales, profits, and employment size, conditional on ownership.

The sample used below includes firms that meet a minimum weeks and hours restriction. Specifically, at least one owner must report working for the business at least 12 weeks in 1992 and at least 10 hours per week. ${ }^{6}$ The weeks and hours restrictions are imposed to rule out very small-scale business activities such as casual or side-businesses owned by wage/salary workers. In multi-owner firms, which represent 20.6 percent of the sample, we identify one person as the primary owner of the business. The primary owner is identified as the owner working the most annual hours in 1992 (weeks*hours). In the case of ties, we identify the primary owner as the person who founded the business. Finally, all remaining ties are resolved by assigning a random owner. The primary business owner is used to identify all owner characteristics of the firm, such as marital status, education, prior work experience, and family business background. The race and sex of the firm, however, are identified by majority ownership, which is the method used by the Survey of Minority Owned Business Enterprises (U.S. Department of Commerce 1996). ${ }^{7}$

to $\mathrm{S}$ corporations due to changes in tax laws (Headd 1999).

${ }^{6}$ This restriction excludes 22.1 percent of firms in the original sample.

${ }^{7}$ The race of the primary owner is not available in the CBO, and the sex of the owner had many missing values. 


\section{Results}

\section{FAMILY BUSINESS BACKGROUND}

Past empirical studies of the intergenerational link in self-employment find that an individual who had a self-employed parent is roughly two to three times more likely to be self-employed than someone who did not have a self-employed parent (Lentz and Laband 1990, Fairlie 1999, Dunn and Holtz-Eakin 2000, and Hout and Rosen 2000). Several explanations for the intergenerational transmission of business ownership have been offered. First, the informal learning or apprenticeship-type training that occurs in growing up in the context of a family business may provide an important opportunity for the acquisition of human capital related to operating a successful business (Lentz and Laband 1990). To be sure, family business experience can be classified into two types, which we term "general business human capital" and "specific business human capital." General business human capital includes "general administrative and personnel management skills" and "general managerial expertise" (Lentz and Laband 1990, Dunn and Holtz-Eakin 2000). Specific business human capital includes "enterprise-specific skills, "information specific to the firm's production," and "job- or industry-specific knowledge."

Another explanation is that intergenerational links in self-employment may be caused by a correlation among family members in preferences for entrepreneurial activities. ${ }^{8}$ The correlation may simply be due to similarities among family members in

\footnotetext{
${ }^{8}$ Dunn and Holtz-Eakin (2000) consider an additional explanation. Successful business owners may be more likely to transfer financial wealth to their children potentially making it easier for them to become self-employed. Their empirical results, however, suggest that it plays only a modest role. Related to this issue we find that financial transfers from parents to children are not a common source of startup capital among small business owners. Only 6.4 percent of owners borrowed capital from their family.
} 
preferences for autonomy or self-employment, or similarities in other personal characteristics that are associated with self-employment, such as entrepreneurial ability and attitudes towards risk (Fairlie 2002).

The CBO provides detailed information on family business experience and business inheritances that allows us to provide some suggestive evidence on the importance of these factors. Table 1 reports the percentage of small business owners that had a family member who was a business owner, the percentage of owners that worked for that family member, and other measures related to family business background. ${ }^{9}$ More than half of all business owners had a self-employed family member prior to starting their business. Conditional on having a self-employed family member, nearly half of small business owners worked in that family member's bus iness. Overall, 22.5 percent of small business owners worked in a family business prior to starting or acquiring their business. ${ }^{10}$

The finding that more than 50 percent of all small business owners had a family member who was a self-employed business owner is nearly identical to the 52.2 percent of independent businessmen from the NFIB that had parents who were business owners (Lentz and Laband 1990). Although we do not have a comparison group of non-business owners and family members may include spouses and siblings in addition to parents, the finding that half of business owners have a self-employed family member suggests a high

\footnotetext{
${ }^{9}$ The questions ask (1) "Prior to beginning/acquiring this business, had any of your close relatives ever owned a business OR been self-employed? (Close relatives refer to spouses, parents/guardians, brothers, sisters, or immediate family)", and (2) "If "Yes," did you work for any of these relatives?" U.S. Department of Commerce (1997, p. C-4).

${ }^{10}$ A recent survey of small employer firms by the NFIB, indicates that 45.1 percent of businesses employ a family member. They use a broader definition of family members than in the CBO and only include firms with 1-249 employees, however (National Federation of Independent Business 2002).
} 
level of intergenerational transmission of business ownership. ${ }^{11}$ The percent of owners that had a self-employed family member prior to business startup certainly overstates the percent of owners that had a self-employed parent, but the discrepancy may not be that large. The strong positive influence of parental self-employment is common to brothers suggesting that a propensity for business ownership runs in families (Dunn and HoltzEakin 2000), and the question on the CBO asks whether the owner had a self-employed family member prior to starting his/her business limiting the likelihood that older siblings are referring to younger self-employed siblings. Furthermore, estimates from the 2002 Current Population Survey indicate that the average probability of having a selfemployed spouse among all self-employed business owners is only 24 percent. We suspect that a large percentage of affirmative responses to the $\mathrm{CBO}$ question on whether the owner had a self-employed family member prior to starting his/her business refer to the owner's parents.

Another interesting finding is that more than half of all business owners who have a self-employed family member did not work for that family member's business. This finding suggests that intergenerational links in self-employment are not solely due to the acquisition of general and specific business capital and that similarities across family members in entrepreneurial preferences may explain part of the relationship. Using data from the National Longitudinal Survey (NLS), however, Dunn and Holtz-Eakin (2000) find that the intergenerational correlation in self-employment is strongest for successfully self-employed parents suggesting that the transmission of business skills instead of

\footnotetext{
${ }^{11}$ Making the conservative assumption that 25 percent of small business owners have a selfemployed parent and a steady-state self-employment rate of 10 percent, the children of selfemployed parents are 3 times more likely to be self-employed than are the children of non-selfemployed parents.
} 
similarities in tastes for the self-employed lifestyle drives the relationship between parents' and children's self-employment propensities.

The $\mathrm{CBO}$ also contains information on whether the owner previously worked "for a business whose goods/service(s) were similar to those provided by this business "(U.S. Department of Commerce 1997, p. C-4). This type of work experience undoubtedly provides opportunities for acquiring job- or industry-specific business human capital in addition to more general business human capital. Slightly more than half of all small business owners report working in a similar business prior to starting their business.

Among owners who worked in a family member's business, 55.8 percent report working in a business that provided similar goods and services. Unfortunately, however, we cannot ascertain whether the family member's business is the same as the business providing similar goods and services. Therefore, our estimate only provides an "upper bound" estimate of the percent of owners who acquired specific business human capital from working in a family member's business. Nevertheless, the estimate of roughly 50 percent suggests that family businesses are providing opportunities to acquire general business human capital and not just specific business human capital. This finding is consistent with the finding in Dunn and Holtz-Eakin (2000) that self-employed sons follow their father's occupation in only 32 percent of cases.

Another explanation is that the children of self-employed business owners become partners with their parents or directly inherit businesses. Forming a partnership with a child may represent a less expensive, especially in terms of capital, method of helping their children become business owners. Also, partnerships and inheritances may 
represent an efficient form of transmitting reputation capital or an established clientele from one generation to the next.

In contrast to the high likelihood of having a self-employed family member and working for that family member, very few small businesses are inherited. Estimates from the $\mathrm{CBO}$ indicate that only 1.6 percent of all small businesses are inherited. This finding suggests that the role of business inheritances in determining intergenerational links in self-employment is limited at best. Lentz and Laband (1990), however, find a much higher rate of business inheritances in their sample of independent businessmen from the NFIB. They find that 14.2 percent of businesses are inherited. The discrepancy may be due to the much larger scale of businesses included in the NFIB. These firms had average sales of approximately $\$ 2$ million in 1979 , compared to $\$ 212,791$ for the CBO sample.

Related to business inheritances, the $\mathrm{CBO}$ includes information on whether the owner acquired the business through a "transfer of ownership/gift." This form of receipt of ownership may capture parents giving firms to their children. Unfortunately, however, it may also contain many other forms of business transfers and is not limited to family members. We find, however, that only 6.6 percent of owners received their business through a transfer of ownership or gift suggesting that direct parent-to-child transfers of businesses cannot represent a large percentage of all small businesses. ${ }^{12}$

Although there is uncertainty over the correspondence between family members and parents in the $\mathrm{CBO}$ questions, the estimates reported in Table 1 provide, at least, some suggestive evidence on the causes of intergenerational links in self-employment.

\footnotetext{
${ }^{12}$ If we remove owners who did not have a self-employed family member prior to starting the business, only 4.0 percent of owners received a transfer of ownership or gift.
} 
These links appear to be driven partly, but not entirely, by opportunities to acquire both general and specific business human capital from working in family members' businesses. Business inheritances and partnerships with family members appear to play only a minor role. We next examine whether these factors play a role in determining small business outcomes conditioning on ownership.

\section{THE DETERMINANTS OF SMALL BUSINESS OUTCOMES}

Logit and linear regression models are estimated for several small business outcomes available in the CBO. Table 2 reports estimates for regressions for the probability of a business closure from 1992-1996, the probability that the firm has profits of at least $\$ 10,000$ per year, the probability of having employees, and log sales. ${ }^{13}$ The Appendix reports mean values for each of the dependent variables. Estimates from the CBO indicate that nearly one quarter of small businesses existing in 1992 were not operating by 1996, and slightly more than 30 percent of businesses report a net profit of at least $\$ 10,000$. Small firms also hire 1.77 employees on average with only 21.3 percent hiring any employees. Finally, small businesses had mean sales of \$212,791 in 1992.

In all specifications, we include the race, sex, region and urbanicity of the firm, and the education level, marital status and previous work experience of the owner as controls (mean values are reported in the Appendix). We also include dummy variables for whether the owner had a family member who was a business owner, worked for that

\footnotetext{
${ }^{13}$ Unfortunately, only a categorical measure of profits is available in the CBO. Estimates for the profit equation using a cutoff of $\$ 25,000$ are similar to those reported below. The other possible cutoff of $\$ 100,000$ yielded too few observations in which the dependent variable equals one. We use a logit model for the employment probability because most of the variation in employment among small businesses is between 0 and 1 employees. Roughly 80 percent of firms have no employees and only a small percent have more than 5 employees.
} 
family member's business, had previous work experience in a managerial capacity, and worked in a business providing similar goods and services.

Race and ethnicity are important determinants of small business outcomes (see Fairlie and Robb 2003 for a more detailed analysis). Asian-owned businesses generally have better outcomes than white-owned businesses. After controlling for numerous owner and business characteristics, black-owned businesses continue to lag behind whiteowned businesses. In all specifications except the closure probability equation, the coefficient estimate on the black-owned business dummy variable is large, positive and statistically significant. In the closure probability equation, the coefficient estimate is positive, but statistically insignificant. The results are more mixed for Latino-owned firms. They have a lower probability of having large profits, but have a higher probability of hiring employees than white-owned firms. The coefficient estimates in the other two specifications are statistically insignificant.

Similar to previous studies, we find that business outcomes are positively associated with the education level of the business owner. ${ }^{14}$ For example, businesses with college-educated owners have a 0.055 lower probability of closure, a 0.113 higher probability of having large profits, a 0.060 higher probability of having employees, and have approximately 25 percent higher sales on average than businesses with owners who did not graduate from high school. ${ }^{15}$ Female-owned businesses are less successful and are smaller on average than are male-owned businesses. Firms located in urban areas are

\footnotetext{
${ }^{14}$ For example, using the 1982 CBO, Bates (1990b) finds that small business failures generally decrease with the education level of the owner. Similarly, Robb (2000) found increases in education to be positively associated with business survival.

${ }^{15}$ The implied effects on the probability of closure, large profits, and employment are approximated by multiplying the coefficient estimate from the logit model by $\bar{p}(1-\bar{p})$, where $\bar{p}$ is the mean of the dependent variable.
} 
more likely to close and are less likely to have employees, but are more likely to have large profits and have higher sales than firms located in non- urban areas.

Having a family business background is important for small business outcomes. The main effect, however, appears to be through the informal learning or apprenticeship type training that occurs in working at a family business and not from simply having a self-employed family member. The coefficient estimates on the dummy variable indicating whether the owner had a family member who owned a business are small and statistically insignificant in all of the specifications except for the closure probability equation. In contrast, working at this family member's business has a large positive and statistically significant effect in all specifications. The probability of a business closure is 0.042 lower, the probability of large profits is 0.032 higher, the probability of employment is 0.055 higher, and sales are roughly 40 percent higher if the business owner had worked for one of his/her self-employed family members prior to starting the business. ${ }^{16}$ The effects on the closure, profit and employment probabilities represent 15.3 to 26.6 percent of the sample mean for the dependent variables.

The findings from the closure equation are roughly consistent with the findings from previous studies. Using a sample of white male-owned firms from the $1982 \mathrm{CBO}$, Bates (1990b) finds that having a close relative who was self-employed has a negative, but statistically insignificant (t-statistic of 1.41) effect on the probability of a business failure. In the 1982 CBO "close relatives," however, are defined to include non-family members with whom frequent contact was maintained by the owner. Fairlie (1999) provides additional evidence from the Panel Study of Income Dynamics (PSID). Having

\footnotetext{
${ }^{16}$ These estimates are not overly sensitive to the exclusion of firms started before 1980. In addition, estimates from the log sales specification are not sensitive to the exclusion of firms with
} 
a self-employed father is found to have a large, negative and statistically significant effect on the probability of exiting from self-employment for white men. Finally, using German data, Bruderl and Preisendorfer (1998) provide some evidence that network support from "strong ties" (which include spouses, parents, and relatives) improves business outcomes. Unfortunately, they do not have information on whether these individuals are business owners.

Perhaps not surprisingly, inherited businesses are more successful and larger than non-inherited businesses. The coefficients are large, positive (negative in the closure equation) and statistically significant in all specifications. Inheritances may represent a form of transferring successful businesses across generations, but their overall importance in determining small business outcomes is slight at best. Although the coefficient estimates are large in the small business outcome equations, the relative absence of inherited businesses (only 1.6 percent of all small businesses) suggests that they play only a minor role in establishing an intergenerational link in self-employment. ${ }^{17}$

The strong effect of previous work experience in a family member's business on small business outcomes suggests that family businesses provide an important opportunity for family members to acquire human capital related to operating a business. The general lack of significance of having a self-employed family member may indicate that correlations across family members in entrepreneurial preferences are less important in contributing to the intergenerational link in business success conditioning on business ownership than in contributing to the intergenerational link in business ownership.

extremely large annual sales.

${ }^{17}$ As expected, the removal of business inheritances from the specifications does not affect the coefficients on other variables. 
The CBO also provides detailed information on other methods of acquiring business human capital. Available questions include information on prior work experience in a managerial capacity and prior work experience in a business whose goods and services were similar to those provided by the owner's business. These variables may have an important effect on small business outcomes.

The effects on small business outcomes of working for a self-employed family member are generally stronger than the effects of previous work experience in a managerial capacity. Management experience has a similar size effect in the profit and employer probability equations, but has a much smaller effect on log sales and a positive and statistically significant effect on business closures. Management experience prior to starting or acquiring a business generally improves business outcomes, but has a less consistent effect than experience working for a close relative.

The CBO also provides information on whether the owner worked in a business whose goods and services were similar to those provided by his/her business. This more general case of acquiring specific business human capital appears to be very important. In fact, the coefficient estimates on a dummy variable for whether the owner had work experience in a similar business are comparable in size to the coefficient estimates on prior work experience in a family member's business in the closure probability and log sales equations. The coefficient estimate is smaller in the employer probability equation, but larger in the profits equation. In all specifications, the coefficient estimates are large and statistically significant.

The inclusion of prior managerial experience and similar business experience suggests that the large, positive coefficient estimates on working for a self-employed 
family member are not simply capturing the effects of management experience or specific business human capital on small business outcomes. Instead, prior work experience in a family member's business has an independent effect on small business outcomes, which may in part be due to the acquisition of less specific, general business human capital.

\section{MISSING DATA}

A concern with the estimates reported in Table 2 is the amount of missing data for some of the independent variables in the CBO. Approximately 10 percent of the observations for each of the specifications reported in Table 3 are excluded because of missing values for one or more of the independent variables. Although these levels of missing data are not extremely high, we examine the sensitivity of our results to two alternative methods of correcting for missing data. First, we estimate regressions in which dummy variables are included for missing values of specific independent variables. ${ }^{18}$ For example, if the education level of the business owner is missing then the four education level dummy variables would be equal to zero and a special missing education dummy variable would be equal to one. Thus, the missing observation for owner's education would not contribute to the coefficient estimates on the main education level dummies, but would contribute to coefficient estimates on other variables. This technique is becoming increasingly common in the literature because it is easy to implement and allows for an increase in the efficiency of some coefficient estimates. Although not reported, we find estimates that are similar to the ones reported in Table 2 for all four specifications.

\footnotetext{
${ }^{18}$ Race, gender, region, and urban are from administrative record data and have no missing values.
} 
We also address the missing data problem by using multiple imputation (see Rubin 1987, Schafer and Olsen 1998, and Schafer 1999 for more details). ${ }^{19}$ The multiple imputation technique essentially replaces each missing value in the data with a set of plausible values resulting in separate datasets that include the true values for nonmissing observations and the imputed variables for missing observations. The imputations are made by examining correlations between all available independent variables and placing restrictions on minimum and maximum values and rounding. ${ }^{20}$ The variables are assumed to have a multivariate normal distribution. Logit or linear regressions are then run on five separately imputed datasets. ${ }^{21}$ The results from the five runs are combined for inference and adjustments are made for sampling variance. The resulting coefficient estimates summarize this information and their standard errors capture the variability of estimates across the five runs, which differs from the typical overstatement of the statistical precision of estimates from single imputation methods. We report the multiple imputation coefficient estimates and their standard errors in Table 3. Despite the large increase in sample size, the estimates are similar to those reported in Table 2. Thus, the removal of observations with missing data does not appear to overly affect our results.

\footnotetext{
${ }^{19}$ The technique has been discussed recently in the Economics literature (Brownstone and Valetta 2001) and has been used to impute income and wealth variables in the Survey of Consumer Finances (Kennickell 1998).

${ }^{20}$ Information from all of the independent variables in the main specification, in addition to information on financial capital, industry, and start year, was used in the correlations.

${ }^{21}$ The gains in efficiency are small after increasing the number of imputations above five
} 


\section{FINANCIAL STARTUP CAPITAL AND INDUSTRY}

Several previous studies find that asset levels play an important role in determining who enters into or exits from self-employment. ${ }^{22}$ Furthermore, small business outcomes vary across industries. Certain industries have higher business turnover rates than others, most notably retail and services (Robb 2000, Reynolds and White 1997, and Humphreys and McClung 1981). Those with higher capital requirements for entry, such as manufacturing and wholesale, typically have lower turnover rates. Barriers of entry into specific industries can result for many reasons. First, capital constraints can limit which industries an individual can enter due to higher capital requirements of certain industries (Bates, 1997). In addition, industry choice may be constrained due to a lack of relevant skills, discrimination, or differences in preferences (Boden, 1996, Boden and Nucci 2000, and Robb 2000). Cooper et al. (1994) shows that industry-specific knowledge contributes to higher survival prospects. The distributions of these variables may be correlated with the family background variables implying that their omission from the regressions may bias the coefficient estimates on the family background variables.

To further explore this concern, we estimate a second set of small business outcome regressions that include dummy variables for different levels of startup capital and major industry categories in addition to the independent variables included in the previous equations. The $\mathrm{CBO}$ contains categorical information on "the total amount of capital required to start/acquire the business" (U.S. Department of Commerce 1997, p. C-

(Schafer and Olsen 1998).

${ }^{22}$ See Evans and Jovanovic (1989), Evans and Leighton (1989), Bates (1990a), Holtz-Eakin, Joulfaian, and Rosen (1994a,1994b), Fairlie (1999), Dunn and Holtz-Eakin (2000), and Blanchflower and Oswald (1998). 
15). Estimates are reported in Table 4. Some caution is required in interpreting the results, however, as the amount of required startup capital is potentially endogenous to business success (Bates 1990b). ${ }^{23}$ Furthermore, the choice of industry may not be entirely exogenous as it is related to the entry decision.

As expected, small business outcomes are positively associated with the amount of required startup capital. The coefficients on the startup capital dummies are large, positive (negative for the closure probability), and statistically significant in all specifications. Industry is also linked to business success and size although the coefficients vary across specifications. More importantly, the addition of startup capital and industry does not overly influence the estimated effects of the family business background and similar business experience variables. The coefficient estimates on having a self-employed family member and inheriting the business do not change substantially. The coefficient estimates on previous work experience in a family member's business are generally smaller in absolute value (although statistically significant) in the new specifications. The coefficients on prior work experience in a similar business are very similar.

\footnotetext{
${ }^{23}$ A similar problem occurs in examining whether asset levels affect the probability of selfemployment using cross-sectional data. A correlation between assts and self-employment may simply represent the ability of the self-employed to accumulate more assets than wage/salary workers through operating and owning their own businesses. The approach taken in several recent studies is to examine transitions into self-employment measuring an individual's net worth prior to starting a business (see Evans and Jovanovic 1989, Evans and Leighton 1989, Meyer 1990, Holtz-Eakin, Joulfaian, and Rosen 1994a, Fairlie 1999, and Dunn and Holtz-Eakin 2000). Unfortunately, the CBO does not contain a measure of the owner's net worth prior to starting the
} 


\section{Conclusions}

Using data from the confidential and restricted-access Characteristics of Business Owners (CBO) Survey, we provide some suggestive evidence on the underlying causes of intergenerational links in self-employment and the related issue of how having a family business background affects small business outcomes. Estimates from the CBO indicate that more than half of all business owners had a self-employed family member prior to starting their business. Conditional on having a self-employed family member, less than half of small business owners worked in that family member's business suggesting that it is unlikely that intergenerational links in self-employment are due solely to the acquisition of general and specific business capital and that similarities across family members in entrepreneurial preferences may explain part of the relationship.

In contrast, estimates from regression models for small business outcomes conditioning on business ownership indicate that having a self-employed family member plays only a minor role relative to prior work experience in that family member's business. We find that the coefficient estimates on the dummy variable indicating whether the owner had a family member who owned a business are small and statistically insignificant in all of the specifications for small business outcomes, except for the closure probability equation. Working in this family member's business, however, has a large, positive and statistically significant effect in all specifications. The inclusion of controls for similar busine ss work experience and management experience in the regressions suggests that the positive coefficient estimates on working for a selfemployed family member are not simply capturing the effects of management experience

business. 
or specific business human capital on small business outcomes. Instead, prior work experience in a family member's business has an independent effect on small business outcomes, which may in part be due to the acquisition of less formal or more general business human capital.

Although many owners had a self-employed family member and previous work experience in a family member's business, very few small businesses were inherited. Estimates from the $\mathrm{CBO}$ indicate that only 1.6 percent of all small businesses were inherited. We also find in the regression analysis that inherited businesses are more successful on average than non-inherited businesses. However, their limited representation among the population of small businesses suggests that business inheritances are only a minor determinant of small business outcomes.

From a policy perspective the findings are important. Most disadvantaged business development policies currently in place, such as set-asides and loan assistance programs, are targeted towards alleviating financial constraints not towards providing opportunities for work experience in small businesses. Even programs providing mentoring, such as the Small Business Administration's 8(a) Business Development Mentor-Protégé Program, generally focus on technical, management and financial assistance, subcontract support, and assistance in performing prime contracts through joint venture arrangements. These programs do not explicitly provide opportunities for would-be entrepreneurs to acquire general and specific business human capital by working for other small business owners. ${ }^{24}$ The findings from this research suggest that

\footnotetext{
${ }^{24}$ The Kauffmann Foundation, however, has a program that provides students with opportunities to work as interns for entrepreneurial ventures. The Kauffmann Entrepreneurial Internship Program has grown rapidly over the past few years and placed 1,800 students at entrepreneurial companies and non-profit organizations in the past year.
} 
governmental programs providing mentoring, internships or apprenticeship-type training may help to reduce historical inequalities in business ownership patterns. ${ }^{25}$ More research, however, is needed on the potential effectiveness of these types of programs especially from evaluations of experimental programs.

25 Apprenticeships are very common in the manufacturing sector in Africa and are associated with substantial returns in self-employment (Frazer 2003). 


\section{References}

Acs, Zoltan J. 1999. Are Small Firms Important? Their Role and Impact, Boston: Kluwer Academic Publishers.

Balkin, Steven. 1989. Self-Employment for Low-Income People, New York: Praeger.

Bates, Timothy. 1990. "The Characteristics of Business Owners Data Base," Journal of Human Resources 25(4): 752-56.

Bates, Timothy. 1990. "Entrepreneur Human Capital Inputs and Small Business Longevity." The Review of Economics and Statistics, 72, November: 551-559.

Bates, Timothy. 1993. Assessment of State and Local Government Minority Business Development Programs. Report to the U.S. Department of Commerce Minority Business Development Agency. Washington, D.C.: U.S. Department of Commerce.

Benus, J. M., Johnson, T. R, Wood, M., Grover, N., \& Shen, T. 1995. Self-employment programs: A new reemployment strategy: Final report on the UI Self-Employment Demonstration (Unemployment Insurance Occasional Paper 95-4). Washington, DC: U.S. Department of Labor, Employment and Training Administration, Unemployment Insurance Service.

Birch, David. 1979. The Job Creation Process, Cambridge, MA: Center for the Study of Neighborhood and Regional Change, Cambridge: MIT Press.

Blanchflower, David G., and Andrew J. Oswald. 1998. "What Makes an Entrepreneur?" Journal of Labor Economics, 16 (1), pp. 26-60.

Boden, Rick and Brian Headd. 2002. "Race and Gender Differences in Business Ownership and Business Turnover." Business Economics, October.

Borjas, George J. 1999. "The Wage Structure and Self-Selection into Self-Employment," Harvard University working paper.

Brown, Charles, James Hamilton, and James Medoff. 1990. Employers Large and Small, Cambridge: Harvard University Press.

Brownstone, David, and Robert Valletta. 2001. "The Bootstrap and Multiple Imputations: Harnessing Increased Computing Power for Improved Statistical Tests," Journal of Economic Perspectives, 15 (4): 129-141.

Bruderl, Josef and Peter Preisendorfer. 1998. "Network Support and the Success of Newly Founded Businesses." Small Business Economics, 10: 213-225. 
Dunn, Thomas A. and Douglas J. Holtz-Eakin. 2000. "Financial Capital, Human Capital, and the Transition to Self-Employment: Evidence from Intergenerational Links," Journal of Labor Economics 18 (2): 282-305.

Evans, David and Boyan Jovanovic. 1989. "An Estimated Model of Entrepreneurial Choice Under Liquidity Constraints." Journal of Political Economy 97(4):808-27.

Evans, David, and Linda Leighton (1989): "Some Empirical Aspects of Entrepreneurship," American Economic Review, 79, pp. 519-535.

Fairlie, Robert W. 1999. "The Absence of the African-American Owned Business: An Analysis of the Dynamics of Self-Employment." Journal of Labor Economics, 17 (1): 80108.

Fairlie, Robert W. 2002. "Drug Dealing and Legitimate Self-Employment," Journal of Labor Economics 20 (3): 538-567.

Fairlie, Robert W., and Alicia M. Robb. 2003. "Why are Black-Owned Businesses Less Successful than White-Owned Businesses: The Role of Families, Inheritances, and Business Human Capital." Joint Center for Poverty Research, Northwestern University and University of Chicago Working Paper \#336.

Frazer, Garth. 2003. "Learning the Master's Trade: Apprenticeship and Firm-Specific Human Capital," University of Toronto Working Paper.

Glazer, Nathan and Daniel P. Moynihan. 1970. Beyond the Melting Pot: the Negroes, Puerto Ricans, Jews, Italians, and Irish of New York City, 2nd Edition. Cambridge: MIT Press.

Guy, Cynthia, Fred Doolittle, and Barbara Fink. 1991. Self-Employment for Welfare Recipients: Implementation of the SEID Program. New York: Manpower Demonstration Research Corporation.

Headd, Brian. 2002. "Redefining Business Success: Distinguishing Between Closure and Failure," Small Business Economics, forthcoming, accepted March 2002.

Headd, Brian. 1999. "The Characteristics of Business Owners Database, 1992." U.S. Census Bureau, Center for Economic Studies, Working Paper Series, CES-WP-99-8.

Holtz-Eakin, Douglas, David Joulfaian, and Harvey Rosen (1994a): "Entrepreneurial Decisions and Liquidity Constraints," Rand Journal of Economics, 23, 2, pp. 334-347.

Holtz-Eakin, Douglas, David Joulfaian, and Harvey Rosen (1994b): "Sticking It Out: Entrepreneurial Survival and Liquidity Constraints," Journal of Political Economy, pp. 53-75. 
Hout, Michael and Harvey S. Rosen. 2000. "Self-Employment, Family Background, and Race," Journal of Human Resources., 35 (4): 670-692.

Humphreys, M.A. \& McClung, J. (1981). Women Entrepreneurs in Oklahoma. Review of Regional Economics and Business, 6 (2), 13-20.

Kennickell, Arthur B. 1998. "Multiple Imputation in the Survey of Consumer Finances," Paper Prepared for the August 1998 Joint Statistical Meetings.

Lentz, Bernard, and David Laband. 1990. "Entrepreneurial Success and Occupational Inheritance among Proprietors," Canadian Journal of Economics, 23, No. 3, pp. 563-579.

Light, Ivan. 1972. Ethnic Enterprise in America. Berkeley: University of California Press.

Light, Ivan. 1979. "Disadvantaged Minorities in Self Employment." International Journal of Comparative Sociology 20(1-2):31-45.

Meyer, Bruce 1990. "Why Are There So Few Black Entrepreneurs?," National Bureau of Economic Research, Working Paper No. 3537.

Moore, Robert L. 1983. "Employer Discrimination: Evidence form Self-employed Workers," Review of Economics and Statistics, 65 (August 1983): 496-501.

National Federation of Independent Business. 2002. National Small Business Poll: Families in Business. NFIB: Washington, D.C.

Raheim, Salome. 1997. "Problems and prospects of self-employment as an economic independence option for welfare recipients," Social Work, 42, 1, pp. 44-53.

Reynolds, P. \& White, S.B. 1997. The Entrepreneurial Process: Economic Growth, Men, Women, and Minorities. Westport, Conn. and London: Greenwood, Quorum Books.

Robb, Alicia. 2002. "Entrepreneurship: A Path for Economic Advancement for Women and Minorities?," Journal of Developmental Entrepreneurship, Volume 7, No. 4.

Robb, Alicia. 2000. "The Role of Race, Gender, and Discrimination in Business Survival", Doctoral Dissertation, University of Michigan Press.

Rubin, Donald B. 1987. Multiple Imputation for Nonresponse in Surveys, New York: John Wiley.

Schafer, Joseph L. 1999. "Multiple Imputation: a Primer," Statistical Methods in Medical Research, 8: 3-15. 
Schafer, Joseph L., and Maren K. Olsen. 1998. "Multiple Imputation for Multivariate Missing-Data Problems: A Data Analyst's Perspective," Multivariate Behavioral Research, 33 (4): 545-571.

Severens, C. Alexander and Amy J. Kays. 1999. 1999 Directory of U.S. Microenterprise Programs. Washington, D.C.: Aspen Institute.

Sowell, Thomas. 1981. Markets and Minorities. New York: Basic Books.

U.S. Department of Commerce. 1996a. 1992 Survey of Minority Owned Business Enterprises: Black.

U.S. Department of Commerce. 1996b. 1992 Survey of Women Owned Business Enterprises.

U.S. Department of Commerce. 1997. 1992 Economic Census: Characteristics of Business Owners.

U.S. Department of Labor. 1992. Self-Employment Programs for Unemployed Workers. Unemployment Insurance Occasional Paper 92-2. Washington, D.C.: USGPO.

Vroman, Wayne. 1997. "Self-Employment Assistance: Revised Report." Urban Institute. 
Table 1

Family Business Background Measures

Characteristics of Business Owners, 1996

\begin{tabular}{|c|c|c|}
\hline & All Firms & Sample Size \\
\hline $\begin{array}{l}\text { Percent of owners that had a self-employed family } \\
\text { member prior to starting firm }\end{array}$ & $51.6 \%$ & 37,740 \\
\hline $\begin{array}{l}\text { Percent of owners that worked in that family member's } \\
\text { business (conditional) }\end{array}$ & $43.6 \%$ & 36,575 \\
\hline $\begin{array}{l}\text { Percent of owners that worked in a family member's } \\
\text { business (unconditional) }\end{array}$ & $22.5 \%$ & 36,575 \\
\hline $\begin{array}{l}\text { Percent of owners that worked at a business with similar } \\
\text { goods/services }\end{array}$ & $50.1 \%$ & 37,238 \\
\hline Percent of owners that inherited their businesses & $1.6 \%$ & 37,619 \\
\hline $\begin{array}{l}\text { Percent of owners that received their businesses as a } \\
\text { transfer of ownership/gift }\end{array}$ & $6.6 \%$ & 37,619 \\
\hline \multicolumn{3}{|c|}{$\begin{array}{l}\text { Notes: (1) The sample includes businesses that are classified by the IRS as individidual } \\
\text { proprietorships or self-employed persons, partnerships, and subchapter } \mathrm{S} \text { corporporations, } \\
\text { have sales of } \$ 500 \text { or more, and have at least one owner who worked at least } 12 \text { weeks and } \\
10 \text { hours per week in the business. (2) All estimates are calculated using sample weights } \\
\text { provided by the CBO. }\end{array}$} \\
\hline
\end{tabular}


Table 2

Logit and Linear Regressions for Small Business Outcomes

Characteristics of Business Owners, 1996

Specification

(1)

\begin{tabular}{lcccc}
\hline Dependent variable & Closure & Profits & Employer & Ln Sales \\
& & $\$ 10,000+$ & Firm & \\
Black-owned business & 0.1203 & -0.8539 & -0.5793 & -0.4636 \\
& $(0.0738)$ & $(0.0991)$ & $(0.1010)$ & $(0.0554)$ \\
Latino-owned business & -0.0784 & -0.2118 & 0.1407 & 0.0660 \\
& $(0.0685)$ & $(0.0689)$ & $(0.0709)$ & $(0.0490)$ \\
Native American-owned & -0.6684 & 0.2015 & 0.4365 & 0.3991 \\
business & $(0.3149)$ & $(0.2533)$ & $(0.2527)$ & $(0.1879)$ \\
Asian-owned business & -0.2598 & 0.1240 & 0.4432 & 0.4709 \\
& $(0.0822)$ & $(0.0693)$ & $(0.0703)$ & $(0.0539)$ \\
Female-owned business & 0.1403 & -1.0073 & -0.3754 & -0.6941 \\
& $(0.0283)$ & $(0.0315)$ & $(0.0313)$ & $(0.0206)$ \\
High school graduate & -0.1189 & 0.2985 & 0.2723 & 0.1534 \\
& $(0.0481)$ & $(0.0536)$ & $(0.0561)$ & $(0.0351)$ \\
Some college & -0.0571 & 0.3460 & 0.2872 & 0.0570 \\
& $(0.0475)$ & $(0.0531)$ & $(0.0554)$ & $(0.0351)$ \\
College graduate & -0.3143 & 0.5414 & 0.3689 & 0.2397 \\
& $(0.0527)$ & $(0.0563)$ & $(0.0591)$ & $(0.0383)$ \\
Graduate school & -0.8470 & 1.0166 & 1.0049 & 0.6115 \\
& $(0.0608)$ & $(0.0583)$ & $(0.0593)$ & $(0.0404)$ \\
Urban & 0.0934 & 0.2137 & -0.2090 & 0.1008 \\
& $(0.0327)$ & $(0.0329)$ & $(0.0334)$ & $(0.0234)$ \\
Prior work experience in a & 0.3722 & 0.1266 & 0.3125 & 0.2089 \\
managerial capacity & $(0.0309)$ & $(0.0303)$ & $(0.0318)$ & $(0.0217)$ \\
Prior work experience in a & -0.2416 & 0.4894 & 0.2631 & 0.4087 \\
similar business & $(0.0281)$ & $(0.0281)$ & $(0.0294)$ & $(0.0202)$ \\
Have a self-employed & -0.1136 & 0.0539 & -0.0133 & -0.0356 \\
family member & $(0.0314)$ & $(0.0321)$ & $(0.0337)$ & $(0.0227)$ \\
Prior work experience in a & -0.2378 & 0.1541 & 0.3365 & 0.3784 \\
family member's business & $(0.0394)$ & $(0.0376)$ & $(0.0385)$ & $(0.0273)$ \\
Inherited business & -0.5723 & 0.5245 & 1.2222 & 1.3144 \\
& $(0.1345)$ & $(0.1039)$ & $(0.0954)$ & $(0.0800)$ \\
Mean of dependent variable & 0.2280 & 0.2980 & 0.2070 & 10.0725 \\
Sample size & 33,485 & 30,500 & 34,179 & 34,179 \\
\hline & & & & \\
& & &
\end{tabular}

Notes: (1) See notes to Table 1. (2) Logit models are used for Specifications 1-3 and OLS is used for Specification 4. (3) Standard errors are in parenthesis below coefficient estimates. (4) All specifications also include a constant, and dummy variables for marital status of primary owner, region, and work experience of the primary owner. 
Table 3

Multiple Imputation Regressions for Small Business Outcomes

Characteristics of Business Owners, 1996

Specification

(1)

(2)

(3)

(4)

\begin{tabular}{|c|c|c|c|c|}
\hline Dependent variable & Closure & $\begin{array}{c}\text { Profits } \\
\$ 10,000+\end{array}$ & $\begin{array}{l}\text { Employer } \\
\text { Firm }\end{array}$ & Ln Sales \\
\hline Black-owned business & $\begin{array}{c}0.1219 \\
(0.0692)\end{array}$ & $\begin{array}{l}-0.8871 \\
(0.0936)\end{array}$ & $\begin{array}{l}-0.6188 \\
(0.0938)\end{array}$ & $\begin{array}{l}-0.4883 \\
(0.0522)\end{array}$ \\
\hline Latino-owned business & $\begin{array}{l}-0.1089 \\
(0.0647)\end{array}$ & $\begin{array}{l}-0.1619 \\
(0.0641)\end{array}$ & $\begin{array}{c}0.0998 \\
(0.0660)\end{array}$ & $\begin{array}{c}0.0552 \\
(0.0463)\end{array}$ \\
\hline $\begin{array}{l}\text { Native American-owned } \\
\text { business }\end{array}$ & $\begin{array}{l}-0.6992 \\
(0.2990)\end{array}$ & $\begin{array}{l}0.1609 \\
(0.2385)\end{array}$ & $\begin{array}{c}0.3877 \\
(0.2362)\end{array}$ & $\begin{array}{c}0.3944 \\
(0.1783)\end{array}$ \\
\hline Asian-owned business & $\begin{array}{l}-0.2708 \\
(0.0773)\end{array}$ & $\begin{array}{c}0.0940 \\
(0.0650)\end{array}$ & $\begin{array}{c}0.4148 \\
(0.0653)\end{array}$ & $\begin{array}{c}0.4549 \\
(0.0508)\end{array}$ \\
\hline Female-owned business & $\begin{array}{c}0.1140 \\
(0.0271)\end{array}$ & $\begin{array}{l}-0.9820 \\
(0.0298)\end{array}$ & $\begin{array}{l}-0.3814 \\
(0.0294)\end{array}$ & $\begin{array}{l}-0.6942 \\
(0.0197)\end{array}$ \\
\hline High school graduate & $\begin{array}{l}-0.1603 \\
(0.0457)\end{array}$ & $\begin{array}{l}0.3013 \\
(0.0515)\end{array}$ & $\begin{array}{l}0.2326 \\
(0.0536)\end{array}$ & $\begin{array}{c}0.1620 \\
(0.0346)\end{array}$ \\
\hline Some college & $\begin{array}{l}-0.1078 \\
(0.0459)\end{array}$ & $\begin{array}{l}0.3487 \\
(0.0501)\end{array}$ & $\begin{array}{c}0.2501 \\
(0.0522)\end{array}$ & $\begin{array}{c}0.0781 \\
(0.0342)\end{array}$ \\
\hline College graduate & $\begin{array}{l}-0.3546 \\
(0.0509)\end{array}$ & $\begin{array}{c}0.5423 \\
(0.0533)\end{array}$ & $\begin{array}{c}0.3235 \\
(0.0578)\end{array}$ & $\begin{array}{c}0.2428 \\
(0.0373)\end{array}$ \\
\hline Graduate school & $\begin{array}{l}-0.9143 \\
(0.0586)\end{array}$ & $\begin{array}{l}1.0396 \\
(0.0566)\end{array}$ & $\begin{array}{c}0.9431 \\
(0.0582)\end{array}$ & $\begin{array}{c}0.6181 \\
(0.0396)\end{array}$ \\
\hline Urban & $\begin{array}{l}0.0979 \\
(0.0315)\end{array}$ & $\begin{array}{c}0.2261 \\
(0.0313)\end{array}$ & $\begin{array}{l}-0.1733 \\
(0.0316)\end{array}$ & $\begin{array}{c}0.1260 \\
(0.0225)\end{array}$ \\
\hline $\begin{array}{l}\text { Prior work experience in a } \\
\text { managerial capacity }\end{array}$ & $\begin{array}{c}0.3535 \\
(0.0303)\end{array}$ & $\begin{array}{c}0.1173 \\
(0.0296)\end{array}$ & $\begin{array}{c}0.3155 \\
(0.0311)\end{array}$ & $\begin{array}{c}0.2395 \\
(0.0228)\end{array}$ \\
\hline $\begin{array}{l}\text { Prior work experience in a } \\
\text { similar business }\end{array}$ & $\begin{array}{l}-0.2421 \\
(0.0281)\end{array}$ & $\begin{array}{c}0.4819 \\
(0.0273)\end{array}$ & $\begin{array}{c}0.2468 \\
(0.0291)\end{array}$ & $\begin{array}{c}0.3862 \\
(0.0208)\end{array}$ \\
\hline $\begin{array}{l}\text { Have a self-employed } \\
\text { family member }\end{array}$ & $\begin{array}{l}-0.1384 \\
(0.0338)\end{array}$ & $\begin{array}{c}0.0827 \\
(0.0310)\end{array}$ & $\begin{array}{l}0.0064 \\
(0.0334)\end{array}$ & $\begin{array}{l}-0.0138 \\
(0.0231)\end{array}$ \\
\hline $\begin{array}{l}\text { Prior work experience in a } \\
\text { family member's business }\end{array}$ & $\begin{array}{l}-0.2227 \\
(0.0475)\end{array}$ & $\begin{array}{l}0.1478 \\
(0.0365)\end{array}$ & $\begin{array}{l}0.3193 \\
(0.0444)\end{array}$ & $\begin{array}{c}0.3607 \\
(0.0327)\end{array}$ \\
\hline Inherited business & $\begin{array}{l}-0.7252 \\
(0.1290)\end{array}$ & $\begin{array}{c}0.6549 \\
(0.0949)\end{array}$ & $\begin{array}{c}1.1851 \\
(0.0867)\end{array}$ & $\begin{array}{r}1.2058 \\
(0.0736)\end{array}$ \\
\hline Mean of dependent variable & 0.2253 & 0.3009 & 0.2131 & 10.0995 \\
\hline Sample size & 37,156 & 33,804 & 38,020 & 38,020 \\
\hline
\end{tabular}

Note: (1) See notes to Table 2. (2) Missing values for all independent variables are imputed. See text for more details. 
Table 4

Logit and Linear Regressions for Small Business Outcomes

Characteristics of Business Owners, 1996

Specification

\begin{tabular}{|c|c|c|c|c|}
\hline & (1) & $(2)$ & (3) & (4) \\
\hline Dependent variable & Closure & $\begin{array}{c}\text { Profits } \\
\$ 10,000+\end{array}$ & $\begin{array}{l}\text { Employer } \\
\text { Firm }\end{array}$ & Ln Sales \\
\hline Black-owned business & $\begin{array}{c}0.0440 \\
(0.0754)\end{array}$ & $\begin{array}{l}-0.8058 \\
(0.1018)\end{array}$ & $\begin{array}{l}-0.4290 \\
(0.1076)\end{array}$ & $\begin{array}{l}-0.3215 \\
(0.0506)\end{array}$ \\
\hline Latino-owned business & $\begin{array}{l}-0.0810 \\
(0.0698)\end{array}$ & $\begin{array}{l}-0.2125 \\
(0.0711)\end{array}$ & $\begin{array}{c}0.1692 \\
(0.0771)\end{array}$ & $\begin{array}{c}0.0735 \\
(0.0447)\end{array}$ \\
\hline $\begin{array}{l}\text { Native American-owned } \\
\text { business }\end{array}$ & $\begin{array}{l}-0.7212 \\
(0.3204)\end{array}$ & $\begin{array}{c}0.1542 \\
(0.2620)\end{array}$ & $\begin{array}{c}0.4246 \\
(0.2767)\end{array}$ & $\begin{array}{c}0.3468 \\
(0.1706)\end{array}$ \\
\hline Asian-owned business & $\begin{array}{l}-0.0519 \\
(0.0848)\end{array}$ & $\begin{array}{l}-0.0843 \\
(0.0719)\end{array}$ & $\begin{array}{l}-0.0999 \\
(0.0783)\end{array}$ & $\begin{array}{c}0.0216 \\
(0.0495)\end{array}$ \\
\hline Female-owned business & $\begin{array}{c}0.0852 \\
(0.0300)\end{array}$ & $\begin{array}{l}-0.9298 \\
(0.0328)\end{array}$ & $\begin{array}{l}-0.3036 \\
(0.0347)\end{array}$ & $\begin{array}{l}-0.5708 \\
(0.0193)\end{array}$ \\
\hline High school graduate & $\begin{array}{l}-0.0371 \\
(0.0495)\end{array}$ & $\begin{array}{c}0.2047 \\
(0.0554)\end{array}$ & $\begin{array}{c}0.1531 \\
(0.0601)\end{array}$ & $\begin{array}{c}0.0324 \\
(0.0325)\end{array}$ \\
\hline Some college & $\begin{array}{c}0.0540 \\
(0.0489)\end{array}$ & $\begin{array}{c}0.3047 \\
(0.0552)\end{array}$ & $\begin{array}{c}0.2426 \\
(0.0596)\end{array}$ & $\begin{array}{c}0.0011 \\
(0.0322)\end{array}$ \\
\hline College graduate & $\begin{array}{l}-0.2460 \\
(0.0548)\end{array}$ & $\begin{array}{c}0.4091 \\
(0.0590)\end{array}$ & $\begin{array}{c}0.2865 \\
(0.0647)\end{array}$ & $\begin{array}{c}0.1441 \\
(0.0355)\end{array}$ \\
\hline Graduate school & $\begin{array}{l}-0.9188 \\
(0.0663)\end{array}$ & $\begin{array}{c}0.7525 \\
(0.0654)\end{array}$ & $\begin{array}{c}1.0214 \\
(0.0700)\end{array}$ & $\begin{array}{c}0.5567 \\
(0.0397)\end{array}$ \\
\hline Urban & $\begin{array}{c}0.0451 \\
(0.0337)\end{array}$ & $\begin{array}{c}0.2920 \\
(0.0342)\end{array}$ & $\begin{array}{l}-0.0879 \\
(0.0362)\end{array}$ & $\begin{array}{c}0.1831 \\
(0.0214)\end{array}$ \\
\hline $\begin{array}{l}\text { Prior work experience in a } \\
\text { managerial capacity }\end{array}$ & $\begin{array}{l}0.4690 \\
(0.0319)\end{array}$ & $\begin{array}{c}0.0359 \\
(0.0316)\end{array}$ & $\begin{array}{l}0.1295 \\
(0.0347)\end{array}$ & $\begin{array}{c}0.0401 \\
(0.0200)\end{array}$ \\
\hline $\begin{array}{l}\text { Prior work experience in a } \\
\text { similar business }\end{array}$ & $\begin{array}{l}-0.2871 \\
(0.0293)\end{array}$ & $\begin{array}{l}0.4605 \\
(0.0294)\end{array}$ & $\begin{array}{c}0.2597 \\
(0.0325)\end{array}$ & $\begin{array}{c}0.4081 \\
(0.0187)\end{array}$ \\
\hline $\begin{array}{l}\text { Have a self-employed } \\
\text { family member }\end{array}$ & $\begin{array}{l}-0.1026 \\
(0.0321)\end{array}$ & $\begin{array}{l}0.0019 \\
(0.0332)\end{array}$ & $\begin{array}{l}-0.0350 \\
(0.0367)\end{array}$ & $\begin{array}{l}-0.0651 \\
(0.0207)\end{array}$ \\
\hline $\begin{array}{l}\text { Prior work experience in a } \\
\text { family member's business }\end{array}$ & $\begin{array}{l}-0.1837 \\
(0.0405)\end{array}$ & $\begin{array}{l}0.1005 \\
(0.0389)\end{array}$ & $\begin{array}{l}0.2098 \\
(0.0422)\end{array}$ & $\begin{array}{c}0.2300 \\
(0.0250)\end{array}$ \\
\hline Inherited business & $\begin{array}{l}-0.4323 \\
(0.1397) \\
\end{array}$ & $\begin{array}{c}0.6465 \\
(0.1140)\end{array}$ & $\begin{array}{l}1.3830 \\
(0.1109)\end{array}$ & $\begin{array}{r}1.3143 \\
(0.0764) \\
\end{array}$ \\
\hline
\end{tabular}


Table 4 (continued)

Logit and Linear Regressions for Small Business Outcomes

Characteristics of Business Owners, 1996

Specification

\begin{tabular}{lcccc} 
Explanatory Variables & $(1)$ & $(2)$ & $(3)$ & $(4)$ \\
\hline Startup capital: & -0.4950 & 0.7202 & 0.9072 & 0.7156 \\
\$5,000-\$24,999 & $(0.0347)$ & $(0.0327)$ & $(0.0360)$ & $(0.0214)$ \\
Startup capital: & -0.7432 & 1.1061 & 1.8769 & 1.4676 \\
\$25,000-\$99,999 & $(0.0512)$ & $(0.0419)$ & $(0.0428)$ & $(0.0291)$ \\
Startup capital: & -1.3036 & 0.8568 & 2.2787 & 2.1520 \\
$\$ 100,000$ or more & $(0.0943)$ & $(0.0598)$ & $(0.0603)$ & $(0.0422)$ \\
Agricultural services & 0.0637 & -0.0532 & -0.9676 & -0.9204 \\
& $(0.0932)$ & $(0.0880)$ & $(0.1021)$ & $(0.0574)$ \\
Mining and construction & 0.2491 & 0.2526 & -0.2151 & -0.2546 \\
& $(0.0546)$ & $(0.0533)$ & $(0.0550)$ & $(0.0350)$ \\
Manufacturing & -0.3550 & 0.1712 & 0.0212 & -0.1055 \\
& $(0.0969)$ & $(0.0795)$ & $(0.0788)$ & $(0.0532)$ \\
Wholesale & 0.0325 & 0.6245 & -0.0038 & 0.6082 \\
& $(0.0841)$ & $(0.0734)$ & $(0.0773)$ & $(0.0518)$ \\
FIRE & -0.3459 & 0.3690 & -1.1322 & -0.4926 \\
& $(0.0620)$ & $(0.0582)$ & $(0.0665)$ & $(0.0367)$ \\
Trans., communications, & 0.3407 & 0.5764 & -0.9290 & -0.3300 \\
and public utilities & $(0.0740)$ & $(0.0705)$ & $(0.0845)$ & $(0.0486)$ \\
Personal services & 0.1107 & -0.2334 & -0.7081 & -0.7430 \\
& $(0.0450)$ & $(0.0459)$ & $(0.0468)$ & $(0.0286)$ \\
Professional services & 0.5529 & 0.3109 & -0.7266 & -0.7021 \\
& $(0.0504)$ & $(0.0524)$ & $(0.0562)$ & $(0.0328)$ \\
Uncoded industry & 0.1124 & -0.4879 & -3.0834 & -0.9842 \\
& $(0.0751)$ & $(0.0876)$ & $(0.2035)$ & $(0.0490)$ \\
Mean of dependent variable & 0.2280 & 0.2975 & 0.2066 & 10.0668 \\
Sample size & 33,116 & 30,271 & 33,701 & 33,701 \\
\hline N & & & & \\
\hline
\end{tabular}

Note: See notes to Table 2. 
Appendix

Means of Selected Variables

Characteristics of Business Owners, 1996

\begin{tabular}{lcc} 
& All firms & Sample size \\
\hline Firm no longer operating in 1996 (Closure) & $22.5 \%$ & 37,156 \\
Net profit of at least $\$ 10,000$ & $30.1 \%$ & 33,804 \\
One or more paid employees & $21.3 \%$ & 38,020 \\
Log sales & 10.10 & 38,020 \\
Married & 0.7993 & 39606 \\
Never married & 0.1418 & 36906 \\
High school graduate & 0.1052 & 36782 \\
Some college & 0.3107 & 36782 \\
College graduate & 0.1921 & 36782 \\
Graduate school & 0.1371 & 36782 \\
Northeast & 0.0583 & 38020 \\
Midatlantic & 0.1452 & 38020 \\
East North Central & 0.1552 & 38020 \\
West North Central & 0.0781 & 38020 \\
South Atlantic & 0.1633 & 38020 \\
East South Central & 0.0493 & 38020 \\
West South Central & 0.1062 & 38020 \\
Mountain & 0.0660 & 38020 \\
Urban & 0.7571 & 38020 \\
Prior work experience: less than 2 years & 0.0731 & 37503 \\
Prior work experience: 2-5 years & 0.1648 & 37503 \\
Prior work experience: $6-9$ years & 0.1513 & 37503 \\
Prior work experience: $10-19$ years & 0.2935 & 37503 \\
Prior work experience: 20 years or more & 0.2529 & 37503 \\
Startup capital: $\$ 5,000-\$ 25,000$ & 0.2350 & 37388 \\
Startup capital: $\$ 25,000-\$ 100,000$ & 0.1126 & 37388 \\
Startup capital: $\$ 100,000+$ & 0.0501 & 37388 \\
Agricultural services & 0.0271 & 38020 \\
Mining and construction & 0.1206 & 38020 \\
Manufacturing & 0.0331 & 38020 \\
Wholesale & 0.0352 & 38020 \\
FIRE & 0.0973 & 38020 \\
Trans., communications, and public utilities & 0.0417 & 38020 \\
Personal services & 0.2630 & 38020 \\
Professional services & 0.1912 & 38020 \\
Uncoded industry & 0.0405 & 38020 \\
\hline Not: See Nos to Table 1. & & \\
\hline
\end{tabular}

Note: See Notes to Table 1. 